\title{
PERCUTANEOUS TRANSTRACHEAL VENTILATION FOR ANAESTHESIA AND RESUSCITATION: A REVIEW AND REPORT OF COMPLICATIONS
}

\section{R. Brian Smith, Walter Beat Schaer, and Hugo Pfaeffle}

Percutaneous transtracheal ventilation with intermittent jets of oxygen under high pressure has been used for approximately five years. It seems timely to review the reports on the use of this technique and to look at recorded complications.

\section{REvIEW}

In 1956 Jacoby $^{1}$ tried objectively to determine values and limitations of transtracheal ventilation in human subjects. Five patients with malignancy in the upper airway scheduled for surgical procedures under general anaesthesia were put to sleep with incremental doses of sodium thiopentone $50 \mathrm{mg}$. Complete respiratory obstruction occurred, in each patient, as unconsciousness developed. An 18-gauge intravenous catheter was inserted into the tracheal lumen, and oxygen was administered at a rate of $41 / \mathrm{min}$. He found that adequate oxygenation can be maintained by this technique for periods of 30 minutes or longer. However, carbon dioxide is ineffectively removed, and $\mathrm{Pa}_{\mathrm{CO}_{2}}$ rapidly rises in apnoeic patients.

Jacobs $^{2}$ advocated transtracheal ventilation as a method for the immediate restoration of an adequate airway in a patient suffering respiratory distress or cardiopulmonary arrest. He used the technique in 12 patients who were comatose and apnoeic. Oxygen under high pressure (60 psi), was applied intermittently with a volume-type ventilator designed and constructed by Jacobs, through a 14-gauge intravenous catheter inserted through the crico-thyroid membrane. Blood gas determinations after 30 minutes revealed a range of $\mathrm{Pa}_{\mathrm{O}_{2}}$ between 180 and $655 \mathrm{~mm} / \mathrm{Hg}$, and a range of a $\mathrm{Pa}_{\mathrm{CO}_{2}}$ between 16 and $53 \mathrm{~mm} / \mathrm{Hg}$. Intrapulmonic pressures were between 15 and $20 \mathrm{~cm} /$ water.

Jacobs $^{3}$ also reported on the use of transtracheal ventilation in 40 apnoeic and terminally ill patients. Blood gases measured at 30 minute intervals in 36 patients showed a range of $\mathrm{PaO}_{2}$ between 120 and $650 \mathrm{~mm} / \mathrm{Hg}$, and $\mathrm{PaCO}_{2}$ between 15 and $54 \mathrm{~mm} / \mathrm{Hg}$. No serious complications occurred.

Spoerel, et al., ${ }^{4}$ testing transtracheal ventilation first in models found that an oxygen jet through a 16-gauge needle at $50 \mathrm{psi}$ could supply enough force to inflate the lungs and the flow produced was adequate to supply the tidal volume for an adult patient without air entrainment. He confirmed these findings in dogs, and demonstrated air entrainment of about 44 per cent when using a tracheal tube. The technique was then applied to 12 patients undergoing routine operations under anaesthesia with intravenous agents and paralysis with d-tubocurarine. A

\section{From The University Health Center of Pittsburgh.}


plastic 16-gauge catheter was inserted into the trachea and an intermittent flow of oxygen was administered at $50 \mathrm{psi}$, generated by a Bird Mark 2 ventilator. Blood gas analysis revealed adequate pulmonary ventilation for periods ranging from 40-75 minutes.

Singh ${ }^{5}$ reported 1,500 cases of transtracheal ventilation for diagnostic and surgical procedures of the upper airways. There were 1,257 cases for bronchoscopy and oesophagoscopy and 135 cases for endolaryngeal surgery. Postoperative ventilatory support was carried out with this technique in 108 cases, ventilated for a period of 24 to 48 hours.

Smith, ${ }^{6}$ and Smith, et al., ${ }^{7,8}$ reported transtracheal ventilation in patients undergoing surgical procedures involving the head and neck. He described the use of this technique in two paediatric patients; one undergoing an operation for laryngeal stenosis, and one who became obstructed and cyanosed in the recovery room. $\mathrm{Pa}_{\mathrm{CO} .}$ determinations at the end of the procedures indicated that the majority of patients were moderately hyperventilated.

Airway obstruction occurs frequently in clinical circumstances. In order to find out how the patterns of pressure and volume are influenced by the presence of an obstruction in the proximal or upper airway during transtracheal ventilation, Chakravarty, et al., ${ }^{9}$ studied these parameters in a model. They found that obstruction of the airway proximal to the jet tends to increase the time required for inflation and deflation of the lung and also produces a higher inflation pressure, all proportional to the severity of the obstruction.

Soft tissue obstruction above the larynx is not likely to create much resistance to expiration, whereas complete obstruction can be produced by stenotic lesions or by the introduction of an instrument into the oropharynx.

It is advisable during laryngoscopy to interrupt the ventilation while the instrument is being introduced and to resume ventilation once the glottis is properly exposed (Spoerel and Greenway). ${ }^{10}$

\section{Complications}

Failure to place the catheter into the trachea correctly at the first attempt is, according to Erasmus, ${ }^{11}$ an indication to postpone the operative procedure or to administer conventional endotracheal anaesthesia, because air can escape through the previous puncture wound and cause surgical emphysema.

Patients with chronic bronchitis and emphysema are probably not good candidates for transtracheal ventilation because of their diminished compliance. Erasmus describes one such case with the $\mathrm{PaCO}_{2}$ rising to $74 \mathrm{~mm} / \mathrm{Hg}$.

Local complications may occur during transtracheal catheterization. Haemorrhage may occur at the site of injection, particularly from the thyroid, and there is always the danger of perforation of the oesophagus if the needle is advanced too far. Another possible complication is subcutaneous emphysema. The plastic catheter with the stylet should be advanced until it has just entered the trachea, the position checked by aspiration of air with a syringe already attached, the stylet withdrawn, and the catheter then inserted without the needle. The catheter should be directed caudad at an angle of 45 degrees. Tissue emphysema can be minimized 
TABLE I

Reported Complications from Transtracheal Ventilation

\begin{tabular}{|c|c|c|c|}
\hline Author & $\begin{array}{l}\text { Number } \\
\text { of cases }\end{array}$ & Complications & \\
\hline Smith $^{6,7,8}$ & 12 & $\begin{array}{l}\text { Subcutaneous emphysema } \\
\text { Mediastinal emphysema } \\
\text { Expiratory obstruction }\end{array}$ & $\begin{array}{l}1 \\
1 \\
1\end{array}$ \\
\hline Spoerel, et al. ${ }^{4}$ & 12 & $\begin{array}{l}\text { Tissue emphysema } \\
\text { Dry cough }\end{array}$ & $\frac{2}{3}$ \\
\hline $\begin{array}{l}\text { Spoerel }{ }^{10} \\
\text { Greenway }\end{array}$ & 15 & Tissue emphysema & 1 \\
\hline Erasmus $^{11}$ & 20 & $\begin{array}{l}\text { Tissue emphysema } \\
\text { Hypercapnia }\end{array}$ & 2 \\
\hline
\end{tabular}

TABLE II

Complications from Transtracheal Ventilation

\begin{tabular}{lcc}
\hline \hline & $\begin{array}{c}\text { Elective prior } \\
\text { to anaesthesia }\end{array}$ & $\begin{array}{c}\text { For acute } \\
\text { respiratory distress }\end{array}$ \\
\hline $\begin{array}{l}\text { No. of patients } \\
\text { Subcutaneous emphysema }\end{array}$ & 52 & 28 \\
Mediastinal emphysema & 5 & 2 \\
Exhalation difficulty & - & $1^{\mathrm{b}}$ \\
Arterial perforation & - & $1^{\mathrm{c}}$ \\
\hline
\end{tabular}

a, b, c, See: Case Reports.

Age Range $10-71$ years.

All patients had pathology of the upper airway (63 Carcinoma larynx or tongue).

by entering the skin at some distance from the tracheal perforation site and by pressure on the trachea after removal of the catheter. A soft catheter is more likely to be displaced if it becomes kinked after removal of the needle. For this reason, it is important to fix the catheter securely.

Complications reported by the authors named are shown in Table I.

\section{Report of Complications from 80 Cases of Transtracheal Ventilation}

At Eye and Ear Hospital, Pittsburgh, transtracheal ventilation has been used in 52 patients electively prior to and during general anaesthesia. It has also been used to resuscitate 28 patients with acute respiratory distress in the operating room.

All patients had pathology of the upper airway. The majority had carcinoma of the larynx or tongue. Their ages ranged from 10 to 71 years.

Complications are shown in Table II. There were no deaths in this series. All patients were successfully resuscitated. Because of the unusual complications, three cases are reported below.

\section{Case a}

A 13-year-old boy was admitted for treatment of an anterior laryngeal web. A tracheostomy and insertion of a tantalum keel into the larynx were planned. 
Because of possible difficulty with the airway, a 14-gauge catheter was inserted percutaneously into the upper trachea under local anaesthesia. Anaesthesia was induced and maintained with intravenous sodium thiamylal 2 per cent (total 400 $\mathrm{mg}$ ) and Innovar ${ }^{\circledR} \mathrm{ml}$. Muscle relaxation was maintained with a drip of succinylcholine 0.2 per cent. Ventilation of the lungs was with intermittent jets of oxygen at 35 psi. Blood gases after 10 minutes of ventilation showed $\mathrm{Pa}_{\mathrm{CO}_{2}} 39$ $\mathrm{mm} / \mathrm{Hg}$ and $\mathrm{Pa}_{\mathrm{O} .2} 429 \mathrm{~mm} / \mathrm{Hg}$. The tracheotomy was accomplished uneventfully and anaesthesia was continued through a tracheal tube inserted into the tracheostomy (halothane, nitrous oxide and oxygen). After insertion of the tantalum keel, the patient was returned to the recovery room breathing spontaneously.

In the recovery room consciousness was regained, and respirations appeared normal. On auscultation of the precordium, a loud "crunching" sound was heard in systole and diastole synchronous with the heart sounds. ${ }^{12}$ Chest X-ray revealed mediastinal emphysema. The following day the "crunch" had disappeared. The patient's recovery was satisfactory.

\section{Case $b$}

A 65-year-old man was admitted to the emergency room unconscious and in severe respiratory distress. The only history immediately available was from his wife who said that he had had an operation on his larynx a year previously, and had gradually become more short of breath. A 14-gauge catheter was inserted percutaneously into the upper trachea, and ventilation of the lungs was performed with intermittent jets of oxygen at $50 \mathrm{psi}$. Within a few minutes the patient started thrashing around, causing the catheter to be displaced. A large amount of oxygen was injected into the tissues, creating severe subcutaneous emphysema of the head and neck. Tracheal intubation was performed with moderate difficulty, and ventilation was continued through the tracheal tube.

Arterial blood gases in the emergency room while breathing 100 per cent oxygen by face mask prior to resuscitation showed a pH of $7.15, \mathrm{~Pa}_{\mathrm{CO}_{2}} 102 \mathrm{~mm} / \mathrm{Hg}$, and $\mathrm{PaO}_{2} 199 \mathrm{~mm} / \mathrm{Hg}$. A review of previous charts indicated that the patient had chronic lung disease. One year previously he had a laryngofissure and removal of the left vocal cord followed by a temporary tracheostomy.

A tracheostomy was performed with the tracheal tube still in place, and the patient was placed on a ventilator. He was weaned from the ventilator after three days. His blood gases prior to discharge were $\mathrm{pH} 7.41, \mathrm{~Pa}_{\mathrm{CO}_{2}} 54 \mathrm{~mm} / \mathrm{Hg}$, and $\mathrm{PaO}_{2} 65 \mathrm{~mm} / \mathrm{Hg}$. A chest roentgenogram following the transtracheal ventilation showed moderate mediastinal emphysema.

\section{Case c}

A 58-year-old male underwent laryngoscopy and biopsy for laryngeal carcinoma. Anaesthesia was induced with halothane, nitrous oxide, and oxygen. After approximately five minutes, total upper airway obstruction occurred. Attempts at tracheal intubation failed. The glottis could not be seen because of distortion of the larynx by carcinoma. Resuscitation was attempted through percutaneous transtracheal ventilation. On palpation of the neck, the trachea could not be identified because of a hard, fixed mass in the neck. By this time the patient was deeply cyanosed. A 14-gauge catheter was inserted in the midline in an attempt to 
enter the trachea. A large artery (probably the internal carotid) was perforated. The catheter was withdrawn and again inserted into the midline of the neck. This time, the trachea was entered. The lungs were ventilated with oxygen intermittently at 50 psi. The patient's colour immediately improved. There was some difficulty with exhalation which was relieved by insertion of a bronchoscope into the larynx. A tracheostomy was done and the patient made an uneventful recovery.

A total laryngectomy and neck dissection was done a week later, and the patient was discharged home soon afterwards.

\section{Conclusions}

The technique of percutaneous transtracheal ventilation has been used successfully for resuscitation and during anaesthesia for approximately five years. In reviewing the literature, no deaths and few serious complications have been reported, particularly with the elective use of this procedure.

This technique has established itself as an important adjunct in life support. When used in properly selected cases, its continued use appears justified.

\section{Summary}

Percutaneous transtracheal ventilation with intermittent jets of oxygen under high pressure has been used for approximately five years. This paper briefly reviews published reports on the use of this technique for resuscitation and during anaesthesia.

Complications occurring in the reports reviewed are tabulated. The complications occurring in a series of 80 patients ( 52 elective prior to anaesthesia and 28 for acute respiratory distress) at the Pittsburgh Eye and Ear Hospital are documented. This includes three detailed case reports.

No deaths and few serious complications have so far been reported, particularly with the elective use of transtracheal ventilation.

This technique has established itself as an important adjunct in life support. When used in properly selected cases, its continued use appears justified.

\section{RÉSUMÉ}

La technique de ventilation transtrachéale percutanée a été utilisée avec succès pour fins de réanimation et d'anesthésie depuis environ cinq ans.

Les auteurs qui ont revu la littérature n'ont pas relevé de décès lié à l'usage de cette méthode et ont noté la très basse incidence de complications graves rapportées, en particulier lorsque la technique était utilisée de façon élective.

L'utilité de cette technique en réanimation est bien établie. Dans certains cas bien définis son usage électif semble amplement justifié.

\section{REFERENCES}

1. Jacoby, J.J., Hameldurg, W., Ziegler, C.H., Floky, F.A., \& Jones, J.R. Transtracheal resuscitation. J.A.M.A. 162:625 (1956).

2. JACOBS, H.B. Emergency percutaneous transtracheal catheter and ventilator. The Journal of Trauma 12: 50 (1972). 
3. JAсовs, H.B. Needle-catheter brings oxygen to the trachea. J.A.M.A. 222: 1231 (1972).

4. Spoerel, W.E., Narayanan, P.S., \& Singh, N.P. Transtracheal ventilation. British J. Anaesth. 43: 932 (1971).

5. SINGH, N.P. Transtracheal jet ventilation as a new technique and experiences with ketamine and propandid in India. Anesthesiology, Proceedings of the Fifth World Congress of Anesthesiologists, Kyoto, September 19-23, 160-161 (1972).

6. SMith, R.B. Transtracheal Ventilation During Anesthesia. Anesthesia and Analgesia 53: 225 (1974)

7. Smith, R.B., MacMillan, B., Petruscak, I., \& PFaeffle, H.H. Transtracheal ventilation for laryngoscopy. Annals of Otology, Rhinology and Laryngology 82: 347 (1973).

8. SMith, R.B., Myers, E.N., \& ShErman, H. Transtracheal ventilation in paediatric patients, Case reports. British J. Anaesth. 46: 313 (1974).

9. Chakravarty, K., Narayanan, P.S., \& Spoerel, W.E. Further studies on transtracheal ventilation: the influence of upper airway obstruction on the patterns of pressure and volume changes. British J. Anaesth. 45: 733 (1973).

10. SPOEREL, W.E. \& GREENWAY, R.E. Technique of ventilation during endolaryngeal surgery under general anaesthesia. Canad. Anaesth. Soc. J. 20:369 (1973).

11. Erasmus, F.R. \& UNGerer, M.J. Transtracheal ventilation during microsurgery of the larynx. S.A. Medical Journal 47: 764 (1973).

12. Hamman, L. Spontaneous mediastinal emphysema. Johns Hopkins Bulletin 64: 1 (1939). 